\title{
Impact of Social Capital on Radical Innovation Efforts of the Organizations: A Case in the Aviation Industry
}

\author{
Sosyal Sermayenin Radikal Yenilik Girişimleri Üzerindeki Etkisi: \\ Havacılık Sektöründe Bir Vaka Çalışması
}

Aytül Ayşe ÖZDEMiR' ${ }^{1}$ Ahmet Emre DEMiRCi²

\begin{abstract}
Social capital stems from the social relationships and yields highly critical benefits such as creativity, innovation and team productivity. However, the context and the structure of the social ties can potentially change the outcomes of social capital. This study aims to reveal the extent and the characteristics of social capital used in the radical innovation efforts. The strength of ties, type of trust and type of knowledge utilized in a selected radical innovation project were analyzed in this research. As an exploratory and descriptive study, case study method was adopted to investigate social capital as a relatively unexplored phenomenon, and to reflect the experiences of relevant individuals in regards to the social relationships embedded in the innovation efforts. The findings indicate that the organization has benefited from the existence and effective use of internal social capital, strong ties were developed and used among the members of the same department, strength of the ties got weaker as the team members, job descriptions and responsibilities started to vary and, finally, the case revealed that competence-based trust and tacit knowledge were found to be the essential parts of creative and innovative thinking.
\end{abstract}

Keywords: Innovation, social capital, strong ties, trust.

\section{INTRODUCTION}

Considering the competitive profiles of many industries, it is obvious that the life cycles of the organizations that are failing to differentiate themselves from their rivals are constantly shrinking. Organizations lacking innovative skills and failing to adapt themselves to the new rules of competition will be facing tough times for survival. If we have a closer look to the lists of the biggest companies in Turkey between 1950 and 1985, some radical changes in the rankings can be clearly seen. While there are new entrants to the list, many companies lost ground against their rivals and many were failed to survive. After 1990s, profiles and the rankings of the Top 100
ÖZET

Sosyal sermaye, sosyal ilişkilerden doğmaktadır ve yaratıcılık, yenilik ve takımların verimliliği gibi önemli yararlar sağlamaktadır. Fakat sosyal bağların yapısı ve içeriği sosyal sermayenin sonuçlarını değiştirmektedir. Bu çalışma, yenilik çabalarında sosyal sermayenin ne derece kullanıldığını ve kullanılan sosyal sermayenin özelliklerini ortaya çıkarmayı amaçlamaktadır. Bir işletmede yenilik çabalarında kullanılan bağların gücü, güvenin türü ve bilginin türü analiz edilmiştir. Literatürde sosyal sermaye hakkında derinlemesine bir bilginin yer almaması, bu araștırmada bireylerin sosyal ilişkilere ilișkin deneyimlerinin tanımlanması isteği, keşfedici ve betimleyici bir çalışma olarak vaka çalışması yapılmasına neden olmuştur. Bulgular, araştırma kapsamındaki işletmede işletme içi sosyal sermayenin kullanıldığı, aynı departmanda çalışan bireyler arasında güçlü bağlar geliştiği ve kullanıldığı, çalışılan departman, görev ve sorumluluklar farklılaştıkça bağın gücünün azaldığı ve uzmanlık temelli güvenin sosyal ağlarda mevcut olduğu şeklindedir.

Anahtar Kelimeler: Yenilik, sosyal sermaye, güçlü bağ, güven

were totally changed while many of these companies failed to position themselves even in the Top 500 . Approximately 30 companies listed in the Top 100 rankings in 1968 are not even listed in the Top 500 rankings today (Ateş, 2007).

Joseph Schumpeter, one of the most influential economists of the 20th century, has considered innovation as a major impetus for change. According to Schumpeter, conventional products and ideas cannot compete with the brand new ones and this process is defined as "Creative Destruction" (Morris, 2006). In short, creative destruction can be defined as a process of industrial mutation that incessantly revolutionizes the economic structure from within,

\footnotetext{
${ }^{1}$ Assist. Prof., Anadolu University, Faculty of Economics and Administrative Sciences, Department of Labour Economics and Industrial Relations, aacengiz@anadolu.edu.tr

${ }^{2}$ Assist. Prof., Anadolu University, Faculty of Economics and Administrative Sciences, Department of Business Administration, aedemirci@anadolu.edu.tr
} 
incessantly destroying the old one, incessantly creating a new one. It is inevitable that a similar end waits for the companies lacking innovation skills. OECD and other EU documents define innovation as; "the transformation of an idea into a new or improved product introduced on the market or a new or improved operational process used in industry and commerce or into a new approach to a social service." (OECD Oslo Manual, 1997).

An essential ingredient of innovation process is creative ideas originated from external and internal sources of organizations. Organizations that have close relationships with their stakeholders are more likely to have higher product and process innovation success. The value of each source depends on the firm's existing stock of knowledge and their ability to access, absorb and exploit new ideas (Rosegger, 1996). Social network theory is about the relationships inside and among organizations (Lin, 2001; Burt, 2000). The relationships are relevant to innovation because it helps to identify, to access resources.

This study mainly aims to reveal the relationship between innovation and social capital. In the study, the role of the human capital and social capital in the innovation process were theoretically discussed. In the final part of the study, innovation efforts of a company were analyzed to explain the qualities of the social capital utilized in these innovation initiatives.

\section{THE ACTORS OF HUMAN CAPITAL IN THE INNOVATON PROCESSES}

In addition to physical and financial resources, staff-related organizational capability factors or, in other words, human capital is very crucial in organizational innovation efforts. Human capital factors can either facilitate or impede innovation speed within the organization. Following conceptual categories are closely related with the existence and speed of innovation initiatives:

\section{Presence of influential champion(s),}

2. The relative strength of leaders assigned to lead project teams,

3. The relative experience of members assigned to work on project teams (Kessler and Chakrabarti, 1996).

As it can be seen from the factors stated above, in addition to financial and physical assets of the organization, human factors including both leaders and the other members of the organization play an important role in the success or the failure of the innovation process.
Champions are generally referred to individual(s) who informally emerge in an organization and make a decisive contribution to innovation by actively and enthusiastically promoting its progress through the critical organizational phases (Howell and Higgins, 1990). In order to deal with the resistance for innovation efforts, organization needs to have champions to promote the idea actively through the use of their personal networks and even to risk his or her position in the organization to ensure the success of the innovation initiative.

Leadership is also a very integral part of the innovation process. They are directly linked to the success or the failure of an innovation process. Leaders within the organization assume both strategic and operational roles and responsibilities when they are involved in innovation initiatives. Leaders should be able to establish and communicate a clear vision. Yet, the word 'vision' here is not referring to corporate vision and long term business goals. It rather refers to a call to develop the conditions, processes and attitudes that characterize an organization as "innovative". In order to support the innovation processes, leaders should also be able to develop competencies and culture for innovation. Last, but surely not least, leaders are responsible for ensuring healthy flow of information within the organization. Both internal and external, as well as formal and informal information is crucial to creativity and learning that in return sparks the innovation initiatives (Le Storti, 2006).

Past experiences of the members are also very crucial in ensuring the success of the innovation process. Lack of experience and/or relevant education of the members can impede the innovation process. Innovation team members should have both technical and interpersonal competencies and experiences. There are several outcomes of having not enough experience related with the innovation process. Among these many outcomes, inexperienced members may underestimate what it takes to get the job done to ensure the success of the innovation process (Cooper, 1999). Kessler and Chakrabarti (1996) suggest that assigning relatively inexperienced individuals to project teams can delay the innovation process.

On the other hand, it is important to look at the other side of the coin. Although the existence of experienced members in the innovation process is important, organizations should also consider assigning relatively inexperienced, in other words newcomers, to project teams. The main reason for such a 
decision is related with idea that the most experienced members are generally older generations. Older and more experienced people are more socialized than the newcomers because they have had more time to observe, accept and adopt predominant norms and values. But on the other hand, they are also the major source of inertial behavior, rigidity and resistance to new solutions that in return impede innovation efforts within the organization (Perretti and Negro, 2007). Thus, balancing the profiles of the members in the innovation team is closely linked to the success and failure of the innovation project.

Closely related with human capital, it is inevitable to consider social capital while discussing the innovation efforts of the organizations (Landry et al, 2000). Resources embedded in the social processes and social relations have great potential to create competitive advantage for the companies.

\section{ROLE OF SOCIAL CAPITAL IN THE INNOVATION PROCESSES}

Innovation should be considered as a dynamic process. Developing new and creative ideas is an integral part of the innovation process. In relation with this idea, social capital consists of networks in which knowledge is created and shared. These profiles clearly establish a solid link between innovation and social capital.

In contrast with the approaches that consider social capital as a "public asset", some theorists consider social capital as a "private asset". According to this approach, "social capital" is a form of capital that exists within a social network that creates ties between the actors (Burt, 1998, 2000; Lin, 2001). This approach extends a way to explain the individual and organizational success in a highly competitive environment. In other words, direct and indirect ties within a social network have great potential to facilitate the actions of actors.

The relationship between social and human capital (Coleman 1990; Schuller 2001; Woolcock 1998) underlies the assumption of the positive effect of social capital on the performance of innovation. Social capital enables organizations to access critical resources such as knowledge that stems from the social relations. Besides, social capital assists organizations while they strive to utilize human capital in a more effective way. Supporting this point of view, ontological view on creating knowledge suggests that knowledge creation processes would fail without social interactions (Nonaka and Takeuchi, 1995).
Nahapiet and Ghoshal (1998) suggest three different dimensions, known as structural, relational and cognitive dimensions, to explain social capital. They also analyzed how each of these dimensions contributes to the sharing of knowledge and the creation of intellectual capital.

Structural dimension of social capital refers to social interaction. Tsai and Ghoshal (1998) suggest that the position of an actor's contacts in a social setting of interactions may provide advantages for the actor. Actors can access valuable resources through the positions they possess in a social structure.

Relational dimension of social capital refers to the nature of the personal relationship between the people as manifested in terms of the strength of the ties. Trust, norms, emotional intensity and intimacy are among the major factors that reflect the strength of the tie (De Carolis and Saparito, 2006).

Cognitive dimension of social capital refers to shared codes, narratives and language (Nahapiet and Ghoshal, 1998; Huysman and Wolf, 2006). Also, Mair and Marti (2006) suggest that cognitive dimension refers to how normative and mimetic forces shape behaviors, and their implications.

Structural social capital, as one of the three dimensions of social capital, considers the social interactions between individuals and groups. Networks themselves are the basis of this dimension (Nahapiet and Ghoshal, 1998). Networks allow organizations to know who possesses what sort of knowledge that in return makes that knowledge more visible for the members of the organization (Davenport ve Prusak, 2000; Floyd and Woolbridge, 1999). Qualities of the networks (network centrality, strength of the ties, structural holes and etc.), specifically implied by the social network theories have varying effects on accessing and sharing knowledge. For example, while the individuals and groups who are positioned at the center of the network receive knowledge in a faster and more intensive way (Tsai, 2001; Tsai and Ghoshal, 1998), strong ties allow individuals to share tacit knowledge (Hansen, 1999; Newell et al., 2004; Hansen et al., 2005).

Especially, ther e is always an ongoing debate on strong and weak ties. According to Granovetter (1973), weak ties among interpersonal relations facilitate to reach particular aims by accessing more social capital. He identified the strength of ties as "the combination of mutual obligations, intimacy, emotional intensity and the amount of time. Strong ties are the ties involve frequent interaction and intense 
emotional relationships; whereas weak ties are conceptualized as the ties involve less interaction and less emotional relationships. The basic argument by Granovetter suggests that a weaker tie is more likely allow you to access more relevant and current information than a stronger tie. Because, a weak tie is more likely to form a bridge between different social circles (Granovetter, 1973). This bridge functions as a unique direct tie between two networks, which does not possess a tie between each other (Burt, 1992). According to weak-tie theory, strong ties are less likely to act as a bridge, because strong ties make the actors familiar with particular qualifications, especially with the knowledge being transferred (Granovetter, 1973).

The benefits of each tie depend on the type of knowledge, process of knowledge creation and the strategy of knowledge creation (Cengiz, 2006). Knowledge can be considered in two different types. Explicit knowledge refers to the type of knowledge that is codified in formal and systemic language. So that, explicit knowledge can be stored, retrieved and transmitted relatively easier through various mechanisms (Ernst and Kim, 2002). On the other hand tacit knowledge refers to the type of knowledge that cannot be codified in formal or systemic language. Tacit knowledge is of paramount importance for individuals to understand the world and accomplish their duties (Choo, 1998). Unlike the explicit knowledge, tacit knowledge embedded and processed within the minds of the individuals, and it can be acquired through practical and relevant experiences. These qualities of tacit knowledge hinder the communication of tacit knowledge to other relevant parties (Stewart, 1997), slow down the knowledge sharing process and increase the communication costs (Grant, 1996; Zack, 1999; Johnson, Lorenz and Lundvall, 2002).

On the other hand, it is more convenient to acquire and share explicit knowledge. Formally coded knowledge can be acquired and then protected by patents and other intellectual property rights (Johnson, Lorenz and Lundvall, 2002).

Weak ties are not proper for transferring tacit knowledge, since interaction is infrequent to interpret and modify the knowledge; moreover tacitness and complexity create ambiguity which has a negative effect on knowledge transfer (Simonin, 1999). Transfer of tacit knowledge may require the development of a shared code in a long-term, strong relationship and working closely (Baum and Ingram,
2000). According to March (1991) strategies linked to knowledge creation aim to explore new opportunities or exploit existing capacities. Complex search, innovation, variation, risk-taking, relaxed control, loose discipline are the concepts that characterizes exploration. In exploratory strategy, the focus is gathering new information on many different alternatives. The emphasis is on identifying viable alternatives rather than fully understanding how to develop any one innovation. In the process of searching knowledge, weak ties are more proper to acquire new knowledge (Hansen, 2005; Kraatz, 1998). Creation and transfer of knowledge require stronger ties. Discussing, sharing, brainstorming and engaging into joint discovery and experiences require strong ties (Gnyawali, 1999). Strong ties are needed for reformulation and validation of new knowledge that requires trust and willingness (Cross and Sproull, 2004).

Another dimension of social capital is referred to as relational social capital. Relational social capital reflects the trust between the individuals and groups. Type of trust is based on benevolence and competence that in return allows the members of the organization to access clear and reliable knowledge in a less costly way (Levin and Cross, 2004; Desouza, 2003; Abrahams et al., 2003). Competence-based trust has a major impact on knowledge transfers involving highly tacit knowledge. When the knowledge required is more experiential, difficult to verify or tacit in nature, the knowledge seeker requires a relatively larger amount of competence-based trust in the provider of that knowledge (Levin and Cross, 2004).

The third dimension of the social capital is called cognitive social capital. This type of social capital consists of several aspects including common language, common codes and vision. Cognitive social capital aims to transfer knowledge from individual level to group level within the organization (Chua, 2002; Un and Cuervo-Cazurra, 2004). The relationship between social capital and innovation becomes crystal clear when we consider that the innovation performance of an organization is heavily depends on some conditions such as the interaction between the members of the organization, norms that facilitate the commitment to organizational vision and mission, and mutual trust within the organization (Baker, 2000).

Existence and enhancement of the social capital would contribute to the development of different types of resources (Cainelli et al., 2007). As long as 
the organization successfully supports the emergence of social capital and manages the relevant processes, major critical resources including knowledge could be acquired and developed in a sustainable way to provide the organization with a competitive advantage.

\section{RESEARCH}

\subsection{Background}

The company we have studied is a leading manufacturer in the aviation industry in Turkey. Within the last three decades, aviation industry in Turkey has progressed at a fast pace. Privatization, coupled with globalization and economic growth, has led to a significant growth in the Turkish aviation industry. In competition with the other emerging economies around the world, Turkish manufacturers operating in the aviation industry were inevitably forced to improve their operations and create their products, services, processes and organizational structures.

The company we have visited has managed to save approximately $10,000,000$ USD annually through radical innovation initiatives targeting its production processes. Led by a visionary idea champion, some scarce and highly expensive production materials were recycled to be used several times along the production process. Supplied by only one vendor in the world, this highly valuable material was used only for once during the manufacturing process before the innovation project directly targeted the re-evaluation of manufacturing processes. Instead of wasting the material after it was used for once, project team innovated the manufacturing process using the material that in return increased the process efficiency by approximately $350-400 \%$.

\subsection{Significance of the Research}

Data collected in this study is aimed to contribute to the studies focusing on the social capital potential of Turkish organizations. Turkish society was attributed with some cultural specifications such as collectivism, high risk avoidance and high power distance (Hofstede, 1980; Paşa et al. 2001; Sargut, 2001; Wasti, 1995). According to Buğra (2000), Turkish society consists of many internal subgroups among which conflictions are common and the level of trust is relatively low. Esmer's (1997) research suggests that the level of trust among Turkish society is very low. Sargut (2001) also argues that, there are numerous sub-groups embedded in the Turkish society and these sub-groups have strong commitment only among their members that in return, creates a mar- ginalization of other individuals and sub-groups within the society. Sargut (2001) suggests that this attitude reduces the general level of trust and synergy within the society. These collectivist attitudes are apparent in the relationships within the families and many other different forms of groups (Kağıtçıbaşı, 1982). Being graduated from the same schools, or being a townsman can be more than enough to bring people together in the same group and create loyalty for each other (Kiray, 1997). Cultural aspects of a society have major impact on the social structure of that specific society. Moreover, it also affects the relationships between the organizations and their stakeholders. The cultural factors representing Turkish culture have considerable impact on the increase in the percentage of family-owned businesses, while hindering institutionalization process and creating aversion for external collaboration opportunities. GLOBE research that considers collectivism in two sub-categories (in-group and institutional) also suggests similar results for Turkey. According to GLOBE research, Turkey scored high in "in-group collectivism" described as the interdependence between the members of a group such as a family or a work group. However, Turkey scored lower in "institutional collectivism" (Kabasakal and Bodur, 2008). At organizational context, Özen and Aslan (2006) claim that external social capital between the organizations is high. However, there are problems about the cooperation and partnerships.

These cultural dimensions create further questions. "How would higher in-group collectivism affect social capital profile of Turkish businesses? Considering the social capital within the organization, what sort of relationship network is developed among the people working in different departments, jobs and areas of expertise? Is that possible to share knowledge within such a relationship network?" are among the major questions that will be addressed in this research.

There is a gap in Turkish literature about internal social capital, and also the relationship between innovation and social capital specifications. This study focuses on the social capital of individuals within an organization. Social relations between the members of an organization and their social interactions with their departments constitute one of the most important sources of social capital. Thus, organization itself is the scope of the analysis. Researchers aim to contribute to the relevant literature with a perspective on the profile of social capital in Turkey from the stand point of "internal social capital" through analyzing 
the structure and context of the relations between the members of a team working in an innovation project.

\subsection{Aim of the Research}

Main goal of this study is to determine the specifications of the social capital utilized in the specific innovation process completed by the company. To achieve this goal, answers to three questions were sought:

$\Leftrightarrow$ What are the specifications of the social capital utilized in the innovation process?

What is the relationship between trust and social ties?

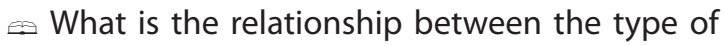
information, trust and ties in the innovation process?

\subsection{Research Method}

Considering the complex nature of the issue and the need to get a deeper understanding about the relationship between social capital and innovation efforts, we have decided to adopt a qualitative approach. The case study design was applied to this research as we aim to reveal the structure and context of the relations between team members and to analyze the causal relations between social capital and innovation performance. As Yin (2003) suggested, "how" and "why" questions are needed to be answered in a research, case study design is beneficial.

Purposive sampling technique was used to select participants. This type of nonrandom sampling is done to increase the utility of information obtained. The primary criteria used to select participants are to take an active role in the innovation project. Within this context, as a result of a purposeful sampling process, operations director and three other members of the project team (Project Engineer (PE), Project Manager (PM) and Production Supervisor (PS)) were interviewed face-to-face for duration of 30 minutes to one hour, in April 2009.

\subsubsection{Data Collection Method and Data Analysis}

Egocentric network approach was used to capture individuals' networks. Semi-structured interviews were the primary data collection tool in this research. Rubin and Rubin (1995) depict semi-structured as: "When researchers want more specific information, they use a semi-structured format. The interviewer introduces the topic, and then guides the discussion by asking specific questions (Rubin and Rubin, 1995). Each individual's interviews were divided among two interviewers, one woman and one man, so that the gender of the interviewer would not affect the observations obtained. Interviews were taped and reports were written in a prescribed sequence, using respondents' actual words. The interview checklist contained questions like the following:

- "Could you please tell us about the first five colleagues that come to your mind in terms of their titles, departments, closeness of your relations and frequency of contacts with him/her within a single week?"

- "Do you meet these five colleagues outside the work environment?"

- "Do you think that these five colleagues possess the required expertise in their jobs?"

- "Do you think that these five colleagues are trustworthy?"

- "Have you acquired any external knowledge from outside individuals/organizations for the innovation project? Could you tell us who they were?"

- Was the external knowledge you have acquired easy to find and openly accessible?"

Interviewers were free to probe for more and other information if they felt it was there. All transcripts, interview notes were reviewed and coded in order to identify themes. Two experts in the field analyzed the transcripts independently according to the pre-defined criteria.

Ethical Considerations: Participants were informed about the aim and the process of the study. Their participance was voluntary; they had the right to withdraw from the study at any time.

Verification Strategies: The major limitation of the study is the lack of multiple data sources. Rich descriptions were used; data and interpretations were sent to participants to check accuracy.

\section{RESEARCH FINDINGS AND EVALUATION}

Findings are organized and presented in concordance with the main goals of the research.

\subsection{Specifications of the Social Capital Utilized in the Innovation Process}

Figure 1 shows the general profile of the social capital utilized in the innovation process. As it can be clearly seen in the figure, company acquires the majority of the information required for the innovation process from the internal networks. The project engineer, project manager and production supervisor are the actors of the primary internal network in which the information is created and shared. Operations di- 
rector and project engineer both hold a Bachelor of Science degree in engineering. Project manager and the production supervisor are vocational school graduates and they both have been involved in relevant tasks for more than 10 years within the company.

We can consider the network size relatively small as the numbers of members in network are not high. Researches in the extant literature reveal that it is easier to access a variety of resources as the network grows bigger (Lin, 2001; Mehra et al., 2001). However, relevant researches also claim that more time and effort would be required to sustain the relationship within the network as the network grows (Hulbert et al., 2000; Uzzi and Gillespie, 1999).

We can consider our network as homogenous one in terms of sex and age, while the network should be considered as heterogeneous in terms of jobrelated knowledge, seniority and status within the organization. According to Reagans and Zuckerman
(2001), within the research and development teams, where the new sources of information is required, heterogeneity about seniority tends to increase the efficiency of the teams. Considering that the relations within this company are defined by the operations director as "simple and cross-functional", it could be claimed that the project network is heterogeneous. On the contrary of heterogeneity, homogeneity refers to have the same qualifications among network members. Homogeneity provides communication effectiveness, behavior expectation and interpersonal trust (Marsden, 1987; Brass and Labianca, 1999).

Strength of ties can be considered as one of the main pillars of social capital. In other words, strength of the ties refers to the frequency and proximity of interactions between the group and individuals (Granovetter, 1973). This pillar, as a channel of sharing knowledge and other resources, plays a crucial role in determining the quality and the benefits of the social capital within the organization.

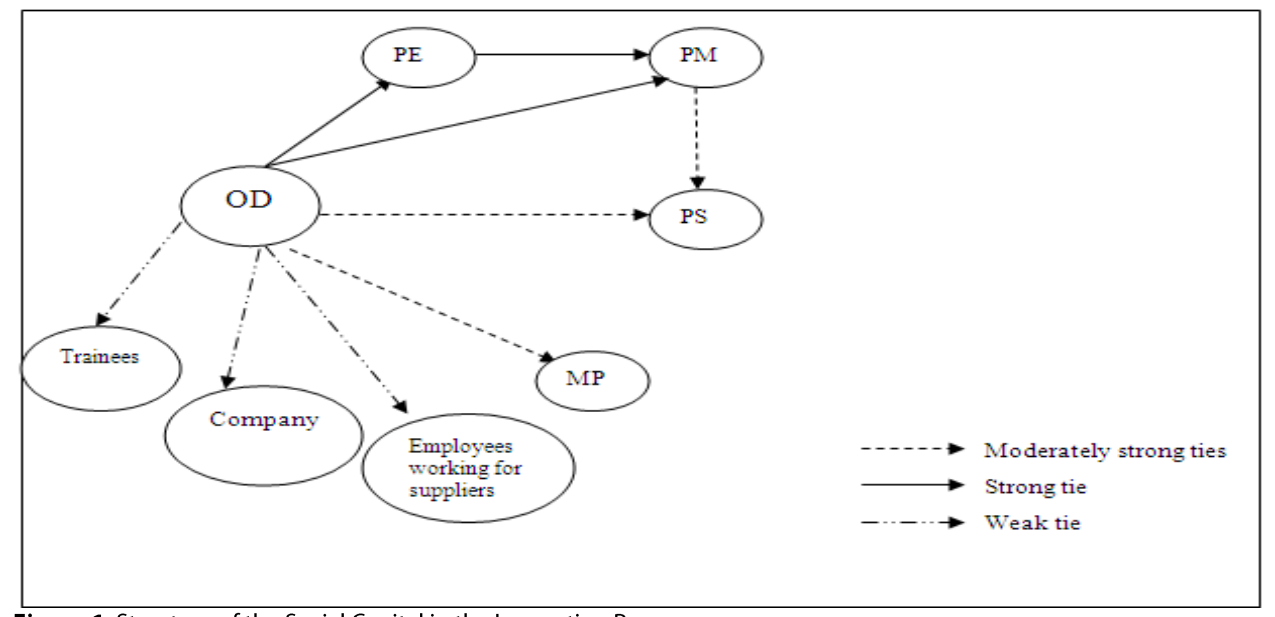

Figure 1: Structure of the Social Capital in the Innovation Process

Our research reveals that there are strong ties between the individuals working in the same department. As the departments start to differ, the level of shared interests decrease and finally duties and responsibilities start to vary, ties between the individuals tend to get weaker. Operations director, project engineer and project manager defined their relationship as being "the members of the same team" and they mentioned that they meet almost every day throughout the project. Below can be seen some statements made by the interviewees regarding the strength of the ties:

- OD: "These guys are like my special ops team... project engineer is very close to me and he is very important for me."
- P.E.: "Project manager is like a son to me; we are close, really close. We are working together for 9 hours a day."

- P.M.: "Whenever I get stucked and get into a problem, I first contact my director and project engineer."

Relations with the product supervisors and materials planners are moderately strong. We have found the relations as task oriented and problem solving focused. Parties come together when/if necessary and relations are moderately close. Some statements are as follows:

- P.M.: "I contact production supervisors only when there is a problem, not in a personal way, just professionally..."; "Relations are strong at work and professional rather than personal". 
- P.S.: "We were in touch with the operations director (OM) almost everyday. There was a strong spirit to handle any problems related with the task and we all were focused on solving problems..."

- P.E.: "Production supervisors are very busy as they are involved in other tasks. We have generally informed them about the task-related issues in this project. They are focused on the end goals, yet loyalty is not that high."; "...However they are closer to us compared to materials planners. MPs may seem a member of our team, but there is always a possibility that they might do something behind our back. Because our relations are not that close..."

- O.D.: "Production supervisors are like mercenaries...." "We are partially close with MPs. We utilize their technical knowledge."

Above mentioned statements clearly shows how internal networks were used within the innovation project. When we asked the question whether there were external networks, the answer was different. We have concluded that the company utilized external networks much less compared to internal networks. Strong ties were replaced with weak ties for the external networks. Relevant statements are as follows:

- O.D.: "We did not utilize external sources of information for this project. Just some minor issues like we have checked the company catalogues to find out more about the production tolerance rates. Main source of knowledge was our know-how. We have slightly benchmarked ourselves against one company." "...We have learned through learning-bydoing; previously idle machineries were put in use again and we have created work cells consist of 40 people from subsidiary industries and interns."

- O.D.: "The company from which we gathered some of the relevant information was not happy with the situation. So, they have provided us with a minimum amount of information. That was a really really distant and remote relationship. However, they had to provide us with some information anyway as they still work with us in other projects..."

\subsection{The Relationship between the Trust and the Strength of the Ties}

As stated in the relevant literature, trust in relations is a crucial requirement in the social networks whereas the information is supposed to be exchanged. When it comes to the creation of knowledge, benevolence based trust and the skills and competency of the knowledge provider becomes prominent (Levin and Cross, 2004). Statements related with the type and determinants of trust embedded in the relations within the innovation process are as follows:

- O.D.: "Project engineer and the project manager are my elite soldiers (Rambo)...." "I fully trust in my project engineer, I am always sure that he would support my decisions. I deal with the issues that he is not able to handle...." "I fully trust in the competency of the project manager. He works like a supervisor. I trust him. Because they are my men. They all were educated by me. Thus, naturally they are closer to me. Supervisors have been working in this company for many years. They are very experiences in their fields. On the other hand, they are very vigilant. I do not trust in them personally. Because their communication network is way too broad and complicated. It is very hard to understand and sense their relations... Materials planners were consulted in their fields of expertise. They did what they had to do. It was their task. I really do not need to trust in them personally while working together." I never trust in the supplier that provides me with knowledge and I don't have to. They always seek a soft spot."

- P.E.: "I delegate some tasks to the project manager. Following up is quite crucial..."; "If you are talking about an innovation project, both the people at the front end and the people in the back office should be good at what they are doing. No matter how he/ she is competent in the job, we still demand trustworthiness. When there is no trust, there is no team". "Relations within the same department are much closer. We work until late hours after 6:00 pm."

- S: I obviously should trust in the project engineer. We work together. If there is no mutual trust, then it is impossible to work together. You cannot work the things out. If there is something to do, then everyone should do his/her best. When it comes to personal trust, I cannot say anything about what would happen in a tricky situation. Teamwork is totally different than individual work. Problems arise when individualism becomes prominent. At this point, any type of trust should be in place. Individualism hinders the performance. Trust is a must if we are talking about a team.....; "I assess people according to their commitment to the company. Our company's own good is a priority. This understanding is the starting point of trust. One should be good at what he/she is doing. If he/she is good, then that makes me feel much better."

- P.M.: "Parts are expensive, trust is important. If someone makes a mistake, he/she should be honest 
about that. Otherwise, we would be misled about the situation. This is an important criterion while building a team. We know people better in time. Personalities and values are very important for us. Of course, intentions are important, too. Members should be easy going people. Is he/she is helping or hindering? This is important. Above all, he/she should be willing to achieve the goals. "Trust is sought for the supervisors. Trust exists when/if you have been working together for some time. Yet, I have closer relations with the operators. I trust in them much more."

As it can be clearly seen in the previous statements, competence based trust is very powerful within the social network related with the innovation projects. Every single person within the team trusts in each other. But, weakening ties, less time worked together, less communication, goal orientation reduce the amount of benevolence based trust. Actually, it becomes unnecessary. Statements of one of the subjects clearly imply this issue:

- "I fully trust in the expertise of the materials planners. I trust in them professionally. But it is the only type of trust. It is not possible to create a personal trust. We do not see each other outside the work environment. At work, we only see each other for 30 minutes. We have met each other when the project started. We even work in different departments."

These statements clearly show that the factors determining the strength of the ties and the factors determining benevolence based trust are the same. Meeting frequency, background of the relation, working in the same department affect the strength of the tie as well as the trust based on benevolence.

5.3. Relation Between the Knowledge Shared in the Innovation Process, Trust and the Strength of the Tie

Knowledge created and shared within the social network involved in the innovation process can be totally classified as tacit. Explicit knowledge has almost never been used within the process. Only, during a visit to a facility of General Electric, some information about the machinery brands and robotics were collected. There is minor flow of external information to the company. Being a high-tech company and risks involved in the uncontrolled share of knowledge are among the factors forcing the company to build the innovation process around its internal networks and the tacit knowledge they possess.
Within the internal networks, trust becomes much more important when the involved knowledge is distinctively valuable and critical. Operations director makes the following statement about this issue:

- "I really do not trust in some of the supervisors. It is great that those I do not trust are not involved in this team. If it was up to me, I would never involve these types of guys in critical projects where special knowledge exists. They spread rumors. Sometimes, you break something while trying to fix another thing. These sorts of things should not be heard by them"

It can be told that tacit knowledge was shared within the social network in this innovation project. Trust among the team members become increasingly important especially when the knowledge is tacit, scarce, critical and valuable. We can argue that trust based on benevolence affects the behaviors of individuals working within the same project team. As mentioned in the statement above, operations director is not willing to be in the same team with people he does not trust. Besides, he does not want his mistakes and failures to be heard by distrusted individuals. Benevolence based trust has been found to be embedded only in the strong ties. This leads to a discussion that implies a strong relation between strong ties, benevolence-based trust and sharing of tacit knowledge.

\section{CONCLUSION}

While some companies are effective in the process of creating and sharing knowledge, others simply fail. Especially when innovation is on the agenda, tacit knowledge is shared more among the employees compared to explicit knowledge and tacit knowledge can be acquired through social networks. Thus, social networks as one of the major factors in creating and sharing knowledge and social capital that involves trust-related issues should be considered and studied.

Our research reveals that the company heavily utilized internal social capital for this specific innovation project. As for the structural dimension of the social capital, knowledge was created and shared through the strong ties. Strong ties among the members of the same department were replaced by weaker ties as the departments and the profile of the tasks change. These results are supported by the relevant literature. Hodson (1996) claims that strong and close ties emerge as a side outcome of the interactions required to complete the task. Besides, 
physical proximity enhances the emergence of trust and strong ties as it increases the density of social interactions (Borgatti and Cross, 2003). From the innovation perspective, gained outcomes through the completion of the project clearly justifies that the organizational efforts led to radical innovation. We can argue that, in the innovation literature, it is widely accepted that radical innovations generally stem from personal form of knowledge created through experiences. And this personal form of knowledge gained through experiences is referred to as tacit knowledge (Polanyi, 1958; Castiaux, 2007). According to Lettl (2007), tacit knowledge possessed by the members of the organization should be considered as one of the major sources of radical innovation. New knowledge is almost always embedded within successful radical innovations efforts. As the radical innovations refer to the extent of innovations that are significantly different than the existing products/services, processes and organizational structures, it requires the creation of new knowledge. Nonaka and Takeuchi (1995) suggest that the creation of new knowledge is characterized by the interaction of codified and tacit knowledge. Thus, we can argue that there is a strong relationship between radical innovations and tacit knowledge. As for our research, we have concluded that the exchange of tacit knowledge among the members of the innovation team facilitated the outcomes. Although we cannot suggest that all ties within the organization are strong enough to share tacit knowledge across the various departments, competence-based trust among the members of the organization and stronger ties within the innovation team led organization to achieve its innovation goal.

As for the relational dimension of the social capital, we have found that competence based trust is embedded in all sorts of relations within the company. According to relevant literature, if/when the tacit knowledge is to be shared and transferred, strong ties and competence based trust are required more than the weaker ties. If the knowledge is complex or if it cannot be coded through some clear instructions, strong ties are strongly required (Hansen, 1999) because covertness and complexity create ambiguity. Companies require healthy social interactions in order to reduce the ambiguity and interpret the tacit knowledge (Newell et al, 2004).

In our case, we claim that the reason why the weaker ties were not utilized was based on the discussions that the weaker ties are generally utilized to seek where the relevant knowledge is. We can also argue that it is much harder for actors to acquire "new" and "rare" knowledge within their own personal networks. Because, it is highly probable that knowledge possessed by one of the actors will also be known by other members within the same relatively closed teams and groups. Consequently, amount of redundant knowledge in such groups can be relatively higher. In order to acquire non-redundant knowledge, actors should access external networks other than their own closed networks. We can argue that weaker ties play an important role in accessing these external networks and learning where the required knowledge can be found.

On the other hand, even if the source of information is known, companies need stronger ties to share the knowledge. For this specific innovation project, competence based trust among the members of the organization is strong and thus the tacit knowledge held by those members can be utilized by the company. As the ties were not that strong within the company, we have hardly seen the benevolence based trust. Trust was identified with personal discipline, commitment to tasks and honesty about the task-related issues. This profile of trust is seen as a critical factor for successfully completing the task.

We have concluded that other dimensions of relational social capital such as reciprocity norm and conforming with the company/team goals are important in creating and sharing the tacit knowledge. Within this framework, benevolence-trust is hindered as the ties get weaker. However, tacit knowledge required for the accomplishment of the project was shared on a regular basis due to reciprocity.

Reciprocity reduces individuality and gathers the individuals around common stakes and common identity. Thus, individuals become the members of a group with shared goals (Adler and Kwon, 2002). Göksel et al. (2010) found similar results in their research and suggested that identification and common language as the elements of relational and cognitive dimensions of social capital have assertive impact on the sharing of tacit knowledge. In our case, we have observed that the supervisors are trusted less within this specific innovation project. Yet, the innovation team constantly received tacit knowledge from the supervisors. Interdependence was found to be the main reason why the tacit knowledge was shared by the supervisors. From the authority stand point, supervisors report to the people leading this innovation project. Besides, any failure in the project is considered as a failure for the company. Conforming to the goals, as another dimension of the relational 
social capital, ensures people to act towards common goals. Within this context, people conforming with the organizational/team goals, share their tacit knowledge to support innovation processes (Nonaka, 1991).

The company studied for this case can be described as a strict one in terms of goal orientation and this goal-oriented profile enhances the professionalism and increases the probability of the emergence of joint efforts towards achieving organizational goals.

Under the context of the study, it is observed that social capital is mainly affected by organizational antecedents. Organizational culture and the level of interpersonal trust have mainly affected the quality of social capital in organizations.

This research is aimed to reveal the profile and structure of the social capital within the organization. We also tried to contribute to the relevant literature in Turkey by presenting the first exploratory qualitative study that analyzes the effects of internal social capital on the innovation efforts of an organization. Social capital literature in Turkey generally focuses on inter-organizational social capital and trust dimension of social capital (Özen and Aslan, 2006; Özkan-Canbolat, 2010; Semerciöz, 2002; Şengün and Wasti, 2006). As a suggestion for future research, comparative study in different cultures regarding the factors facilitating the creation of benevolence-based trust can be done. Our research showed that the creation of benevolence-based trust is facilitated by the factors such as physical closeness, meeting frequency and level of familiarity. Also, research found that reciprocity, as a dimension relational social capital, and dedication for organizational goals assertively impact knowledge sharing process among the individuals within the organization. These results can be analyzed by a quantitative research on a bigger sample in future research.

Social capital needs to be managed properly. In order to increase the level of social capital, organizations are required to dedicate more resources on the factors that facilitate the creation of social capital. Future research can focus on the strategies for managing social networks and social capital in consideration of the dynamics of Turkish culture such as its collectivist structure and relatively low level of trust. Ozdemir's (2007) research suggests that the faculty members have relatively closed, smaller and homogenous social networks where weaker ties are seldomly used. On the other hand, Uzzi $(1999 ; 2003)$ suggests that both weaker and stronger ties should be adopted depending on which one complies with the goals of the actors. From the innovation management perspective, future research can also focus on the paradoxical relations between innovation performance and strong vs. weak ties. The relationship between innovation performance and the strength of the ties are not linear and thus, the factors affecting the nature of this relationship should be considered. 


\section{END NOTES}

i The extended abstract of this article was presented at 19. National Management and Organizational Conference and published in Conference Proceedings. ii Company name is not revealed due to their request to keep their commercial name anonymous

\section{REFERENCES}

Abrahams, L.C., Cross, R., Lesser, E. \& Levin, D.Z. (2003) "Nurturing Interpersonal Trust in Knowledge Sharing Networks" Academy of Management Executive, (4):64-79.

Adler, P. S. \& Kwon, S.W. (2002) "Social Capital: Prospects for a New Concept" Academy of Management Review, 27(1):17-40.

Ateş, R. (2007) İnovasyon Hayat Kurtarır, 1.Bask1, İstanbul, Doğan Kitapçılık.

Baker, M. (2000) Achieving Success Through Social Capital, USA, Jossy Bass.

Baum, J. \& Ingram, P. (2000) "Interorganizational Learning and Network Organization: Toward a Behavioral Theory of the Firm",http://bic.mgmt.utoronto. ca/2000-04.pdf.

Borgatti, P.S. \& Cross, R. (2003) "A Relational View of Information Seeking and Learning in Social Networks” Management Science, 49(4):432-445.

Brass, D.J. \& Labianca, G. (1999) "Social Capital, Social Liabilities and Social Resource Management", Roger Th. A.J. Leenders, Shaul M.Gabbay (eds.), Corporate Social Capital and Liability, USA, Kluwer Academic Publishers.

Buğra, A. (2000) Devlet-Piyasa Karşıtlı̆̆ının Ötesinde: İhtiyaçlar ve Tüketim Üzerine Yazılar, Çev. Bahadır Sina Şener, İstanbul, İletişim Yayınları.

Burt, R. S. (1992) Structural Holes: The Social Structure of Competition, Harvard, Harvard University Press.

Burt, R. S. (1997) "The Contingent Effect of Social Capital" Administrative Science Quarterly, 42(2):339366.

Burt, R.S. (1997) "A Note on Social Capital and Network Content” Social Networks, 19:355-373.

Cainelli, G., Mancinelli, S. \& Mazzanti, M. (2007) "Social Capital and Innovation Dynamics in DistrictBased Local Systems" The Journal of Socio-Economics, 36(6):932-948.

Castiaux, A. (2007) "Radical Innovation in Established Organizations: Being a Knowledge Predator" Journal of Engineering and Technology Management, 24(1):36-52.
Cengiz, A.A. (2006) Literature Review: The Paradox of Social Network Ties in Creating Knowledge, Proceedings of Global Conference on Emergent Business Phenomena in the Digital Economy, Tampere University of Technology, Finland, 28 Nov-2 Dec.

Choo, C.W. (1998) The Knowing Organization, Oxford University Press.

Chua, A. (2002) "The Influence of Social Interaction on Knowledge Creation" Journal of Intellectual Capital, 3(4):375-392.

Coleman, J. (1990) Foundations of Social Theory, England, The Belknap Press of Harvard University Press.

Cooper, R. G. (1999) "From Experience: The Invisible Success Factors in Product Innovation" Journal of Product Innovation, 16(2):115-133.

Cross, R. \& Sproull, L. (2004) "More Than An Answer: Information Relationships for Actionable Knowledge" Organization Science, 15(4):446-462.

Davenport T. \& Prusak H. L. (2000) Working Knowledge: How Organizations Manage What They Know?, Boston, Harvard Business School Press.

De Carolis, D.M. \& Saparito, P. (2006) "Social Capital, Cognition, and Entrepreneurial Opportunities: A Theorotical Framework" Entrepreneurship Theory and Practice, 30(1):41-56.

Desouza, K.C. (2003) "Knowledge Management Barriers: Why the Technology Imperative Seldom Work?” Business Horizons, 46(1):25-29.

Esmer,Y (1997) Devrim, Evrim, Statüko: Türkiye’de Sosyal, Siyasal, Ekonomik Değerler, İstanbul, TESEV Yayinlari.

Ernst, Dieter \& Kim, Linsu (2002) "Global Production Networks, Knowledge Diffusion, and Local Capability Formation" Research Policy, 31(9):1417-1429.

Floyd, S.W. \& Woolbridge, B. (1999) "Knowledge Creation and Social Networks in Corporate Entrepreneurship: The Renewal of Organizational Capability" Entrepreneurship Theory and Practice, 23(3):121-143.

Granovetter, M. (1973) “The Strength of Weak Ties" American Journal of Sociology, 78(6): 1360-1380. 
Hansen, M.T. (1999) "The Search-Transfer Problem: The Role of Weak Ties in Sharing Knowledge Across Organizational Subunits", Administrative Science Quarterly, 44(1):82-112.

Hansen, M., Marie L. \& Lovas, B. (2005). Knowledge Sharing in Organizations: Multiple Networks, Multiple Phases. Academy of Management Journal, 45 (5):776-799.

Hodson, R. (1996) "Dignity in the Workplace Under Participative Management: Alienation and Freedom Revisited" American Sociological Review, 61(5):719-738.

Hofstede, G. (1980) Culture's Consequences: International Differences in Work-Related Values, Newbury Park, C A. Sage.

Howell, J. M. \& Higgins, C.A. (1990) "Champions of Technological Innovation" Administrative Science Quarterly, 35(2):317-341.

Hulbert, J.S., Haines, V.A. \& Beggs, J.J. (2000) "Core Networks and the Activation of Ties" American Sociological Review, 65(4):598-618.

Huysman, M. \& Wulf, V. (2006) "IT to Support Knowledge Sharing in Communities, Towards A Social Capital Analysis" Journal of Information Technology, 21:40-51.

Johnson, B., Lorenz, E., \& Lundvall, B. (2002) "Why all This Fuss about Codified and Tacit Knowledge?" Industrial and Corporate Change, 11(2):245-262.

Göksel, A., Aydıntan, B. \& Bingöl, D. (2010) "Örgütlerde Bilgi Paylaşım Davranış: Sosyal Sermaye Boyutuyla Bir Bakış" Ankara Üniversitesi SBF Dergisi, 65(4):87-109.

Gynawali, D.R. (1999) "Interorganizational Learning Dynamics: Roles of Networks on Knowledge Creation"

http://notes.lancs.ac.uk/pub/ol3.nsf/0/2900de63 51042d958025676100505844/\$FILE/Gnyawali.pdf, (25.06.2006).

Kabasakal, H. \& Bodur, M.(2008) "Leadership and Culture in Turkey: A Multi-faceted Phenomenon" Jagdeep, S. Chhokar, Felix C. Broadbeck and J.R.House (eds.) Culture and Leadership Across the World, USA, Taylor\&Francis.

Kağıtçıbaşı, Ç. (1982) The Changing Value of Children in Turkey, Papers of East-West Population Institute, No:60.

Kessler, E. H. \& Chakrabarti, A. K. (1996) "Innovation Speed: A Conceptual Model of Context, Antecedents, and Outcomes" Academy of Management, 21(4):1143-1191.
Kiray, M. (1997) Abondonment of Land and Transformation to Urban Life, Human Development Report, Ankara, Turkey, UNDP.

Kraatz, M.S. (1998) "Learning by Association: Interorganizational Networks and Adaptation to Environmental Change" Academy of Management Journal, 41(6):621-643.

Landry, R., Amara, N. \& Lamari, M. (2000) Does Social Capital Determine Innovation ? To What Extent? Proceedings of 4th International Conference on Technology Policy and Innovation, Brazil.

Le Storti, A. J. (2006) "Leadership for Innovation: What Leaders Must Do for Innovation to Happen" Howe School for Technology Management, 2(10):1-5.

Lettl, C. (2007) "User Involvement Competence for Radical Innovation" Journal of Engineering and Technology Management, 24(1):53-75.

Levin, D.Z. \& Cross, R. (2004) "The Strength of Weak Ties You Can Trust: The Mediating Role of Trust in Effective Knowledge Transfer" Management Science, 50 (11):1477-1490.

Lin, N. (2001) Social Capital : A Theory of Social Structure and Action, USA, Cambridge University Press.

Mair, J \& Marti, I. (2006) "Social Entrepreneurship Research: A Source of Explanation, Prediction, and Delight" Journal of World Business, 41(1):36-44

March, J.G. (1991) "Exploration and Exploitation in Organizational Learning” Organization Science, 2(1):7188.

Marsden, P.W. (1987) "Core Discussion Networks of Americans" American Sociological Review, 52(1):122-131.

Mehra, A. Kilduff, M. \& Brass, J. D. (2001) "The Social Networks of High and Low Self-Monitors: Implications for Workplace Performance" Administrative Science Quarterly, 46: 121-146.

Morris, L. (2006) Permanent Innovation, USA, Innovation Academy.

Nahapiet, J. \& Ghoshal, S. (1998) "Social Capital, Intellectual Capital and the Organizational Advantage" Academy of Management Review, 23(2):242-286.

Newell, S., Tansley, C. \& Huang, J. (2004) "Social Capital and Knowledge Integration in on ERP Project Team: The Importance of Bridging and Bonding" British Journal of Management, 14:43-57.

Nonaka, I. (1991) "The Knowledge Creating Company" Harvard Business Review, 69:96-104. 
Nonaka \& Takeuchi, H. (1995) The Knowledge-Creating Company: How Japanese Companies Create The Dynamics of Innovation. Oxford, Oxford University Press.

OECD (1997) Oslo Manual, European Commision, Eurostat.

Özen, Ş. \& Aslan, Z. (2006) "İçsel ve Dışsal Sosyal Sermaye Yaklaşımları Açısından Türk Toplumunun Sosyal Sermaye Potansiyeli: Ortadoğu Sanayi ve Ticaret Merkezi (OSTIM) Örneği” Akdeniz Üniversitesi İ.I.B.F. Dergisi, 6(12):130-160.

Özdemir, A. A. (2007) "Sosyal Ağ Özellikleri Bakış Açısıyla Sosyal Sermaye ve Bilgi Yaratma İlişkisi: Akademisyenler Üzerinde Yapılan Alan Araştırması" Yayımlanmamış Doktora Tezi, Eskişehir, Anadolu Universitesi Sosyal Bilimler Enstitüsü.

Özkan-Canbolat, E. (2010) "Örgütlerin İçinde Bulunduğu Ağ Şebekelerindeki Konumlarının Örgütsel Alandaki Eşbiçimliliğe Etkisi” Organizasyon ve Yönetim Bilimleri Dergisi, 2(1):1-10.

Paşa, F. S., Kabasakal, H. \& Bodur, M. (2001) "Society, Organizations and Leadership in Turkey" Applied Psychology: An International Review, 50(4):559-589.

Perretti, F. \& Negro, G. (2007) "Mixing Genres and Matching People: A Study in Innovation and Team Composition in Hollywood" Journal of Organizational Behavior, 28:563-586.

Polanyi, M., (1958) Personal Knowledge: Towards a Post-Critical Philosophy. London, Routledge \& Kegan Paul.

Reagans R. \& Zuckerman, E. W. (2001) "Network, Diversity, and Productivity: The Social Capital of Corporate R\&D Teams" Organizational Science, 12(4):502517.

Rubin H.J. \& Rubin I.S. (1995) Qualitative Interviewing: The Art of Hearing Data, United Kingdom, Sage Publications.

Sargut, A. (2001) Kültürler Arası Farklilaşma ve Yönetim, Ankara, İmge Kitabevi.

Schuller, T. (2001) "The Complementary Roles of Human and Social Capital" ISUMA, 42(1):17-24.

Semerciöz, F. (2002) "Endüstriyel Bölgeler ve Bu Bölgelerdeki İşletmelerarası İlişkiler: Merter Teksitl Bölgesi Örneği” 9.Ulusal Yönetim ve Organizasyon Kongresi Bildirisi, İstanbul.
Şengün, A.E. \& Wasti, S.N. (2006) "Alıcı-Satıcı İlişkilerinde Güvenin Performansa Etkileri: Eczane-Ecza Deposu İlişkisi Örneği” ODTÜ Gelişme Dergisi, 33:223254.

Tsai, W. (2001) "Knowledge Transfer in Intraorganizational Networks: Effects of Network Position and Absorptive Capacity on Business Unit Innovation and Performance" Academy of Management Journal, 44(3):996-1004.

Tsai, W. \& Ghoshal, S. (1998) "Social Capital and Value Creation: The Role of Intrafirm Networks" Academy of Management Journal, 41(4):464-478.

Un, C. A. \& Cuervo-Cazurra, A. (2004) "Strategies for Knowledge Creation in Firms" British Journal of Management, 15:27-41.

Uzzi, B. \& Gillespie, J. J. (1999) "Corporate Social Capital and the Cost of Financial Capital: An Embeddedness Approach" Roger Th. A.J. Leenders, Shaul M.Gabbay (eds.) Corporate Social Capital and Liability, USA, Kluwer Academic Publishers.

Uzzi, B. and Lancaster, Ryon. (2003) "Relational Embeddedness and Learning: The Case of Bank Loan Managers and Their Clients" Management Science, 49(4):383-399.

Wasti, A.S. (1995) "Kültürel Farklılaşmanın Örgütsel Yapı ve Davranışa Etkileri: Karşılaştırmalı Bir İnceleme” ODTÜ Gelişme Dergisi, 22(4):503-529.

Woolcock, M. (1998) "Social Capital and Economic Development: Toward a Theoretical Synthesis and Policy Framework" Theory and Society, 27(3):151-160.

Rosegger, G. (1996) "Firms' Information Sources and the Technology Life Cycle" International Journal of Technology Management, 12:704-716.

Yin, R.K. (2003) Case Study Research: Design and Method, Oaks, Sage Publications.

Simonin, B.L. (1999) "Ambiguity and the Process of Knowledge Transfer in Strategic Alliances" Strategic Management Journal, 27(3):595-623.

Zack, M. (1999) "Managing Codified Knowledge. Sloan Management Review" 40(4):45-58. 